\title{
UNFAITHFUL EXECUTION OF THE LAW: CONGRESSIONAL INTERFERENCE WITH AGENCY DECISION-MAKING
}

William Alan Nelson*

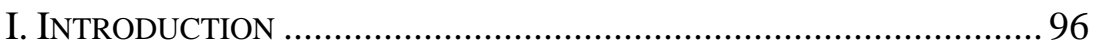

II. CONGRESSIONAL INTERFERENCE WITH AGENCY DECISION-

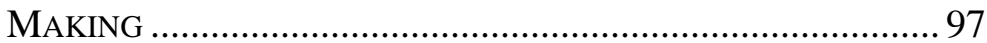

A. Congressional Rules and Guidance .................................97

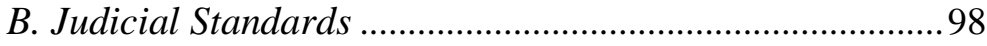

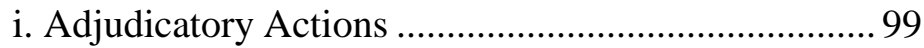

ii. Non-Adjudicatory Actions ................................... 102

iii. Rulemaking Actions............................................ 103

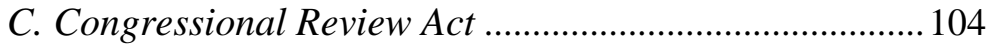

III. EfFectuating Policy Change Through Substantive

APPROPRIATIONS RIDERS .................................................. 107

A. Congressional Rules and Guidance............................... 107

IV. POLICY Riders In APPROPRIATIONS MEASURES ARE

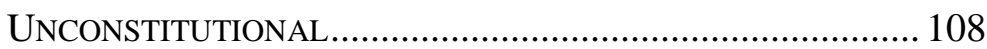

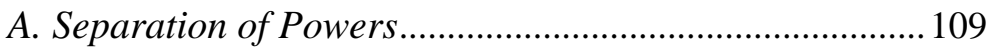

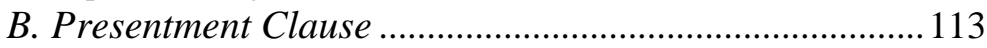

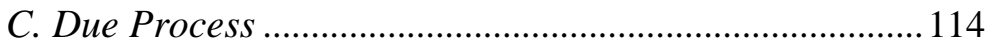

V. Policy Riders Are Not An EfFective Policymaking

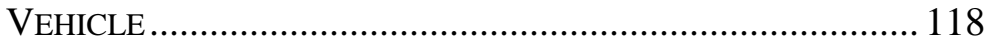

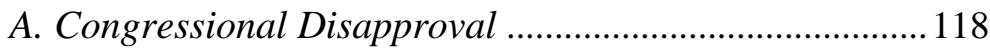

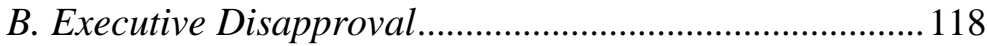

C. Normal Legislative Process Encourages Informed

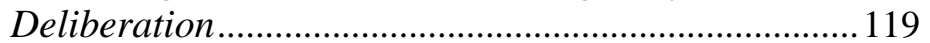

D. Policy Riders Negate Public Notice and Comment....... 120

VI. CASE STUDIES................................................................... 122

A. Retail Investor Protection Act (H.R. 1090) .................... 122

\footnotetext{
* Adjunct Professor, George Washington University Law School; Deputy General Counsel and Chief Compliance Officer, Mercer Advisors Inc. The views and opinions expressed in this article are solely those of the author and do not necessarily represent the views and opinions of, and should not be attributed to, Mercer Advisors. I would like to thank the Seton Hall Legislative Journal editorial staff for their dedication in readying this Article for publication. I would also like to dedicate this Article to my wife Emily and daughter Abigail, whose constant love, support, and encouragement have sustained me beyond measure.
} 


\section{B. Protecting American Families' Retirement Advice Act}

(H.R. 355)

C. Require Evaluation before Implementing Executive

Wishlists Act (H.R. 3438).....

D. Regulations from the Executive in Need of Scrutiny Act (H.R. 427)

VII. SOLUTIONS

A. Enforce Congressional Rules ........................................ 125

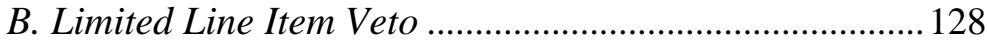

VIII. CONCLUSION

"When the legislative and executive powwers are united in the same person, or in the same body of magistrates, there can be no liberty." Charles de Secondat, Baron de Montesquieu ${ }^{1}$

\section{INTRODUCTION}

Under the United States Constitution ("Constitution"), Congress has the power to create laws ${ }^{2}$ and holds the power of the purse, ${ }^{3}$ while the President ensures that the laws are faithfully executed. ${ }^{4}$ The separation of powers is something that American schoolchildren are taught from a young age; Congress passes laws and funds the agencies, and departments of the executive branch implement and enforce those laws. The judiciary has also illustrated the division of power between the executive and legislative branches of government. ${ }^{5}$ However, while this division seems straightforward, Congress has slowly increased its control over the activities of the executive branch through directly influencing administrative proceedings and through the use of substantive policy riders in the appropriation process. ${ }^{6}$ In fact, since the 1870 s, Congress has attached policy riders to appropriation bills. ${ }^{7}$

1 Charles de Secondat, Baron de Montesquieu, The Spirit of the LaWs (1748), http://sourcebooks.fordham. edu/mod/montesquieu-spirit.asp.

2 U.S. CONST. art. I, $\S 8$, cl. 18 (Congress shall have the power to "make all Laws which shall be necessary and proper for carrying into Execution the foregoing Powers.").

3 U.S. CONST. art. I, $\S 9$, cl. 7 ("No money shall be drawn from the Treasury, but in Consequence of Appropriations made by Law.").

4 U.S. Const. art. II, $\S 3$ (The President "shall take Care that the Laws be faithfully executed").

5 Springer v. Philippine Islands, 277 U.S. 189, 202 (1928) ("Legislative power, as distinguished from executive power, is the authority to make laws, but not to enforce them"); J. W. Hampton, Jr., \& Co. v. United States, 276 U.S. 394, 406 (1928) (Congress may not "invest itself or its Members with either executive power or judicial power.").

6 Neal E. Devins, Regulation of Government Agencies Through Limitation Riders, 1987 DuKE L.J. 456, 462 (1987).

7 Id. ("By the 1940s, the use of riders was so widespread that the Joint Committee on 
This Article investigates the legality and utility of Congressional interference in the administrative process. Part II discusses direct Congressional interference in agency decision-making. Part III examines the use of substantive appropriations riders to effectuate policy change. Part IV argues that substantive limitations placed on administrative agencies in the appropriations process are unconstitutional. Part V discusses how, regardless of the constitutionality, limitation policy riders are not an effective policymaking vehicle. Part VI provides case studies illustrating how current legislation possibly violates multiple clauses of the Constitution. Part VII offers solutions to address the problems arising from the use of policy riders in the appropriation process. From the outset, it is important to note that Congress has the constitutional ability to alter agency policy by simply passing a statute ${ }^{8}$ however, this Article focuses on Congressional interference through other means. Part VIII concludes.

\section{CONGRESSIONAL INTERFERENCE With AgENCY DeCISION-MAKING}

Currently, no federal law or internal rule prohibits a Member of Congress ("Member") in the Senate or House of Representatives ("House") from becoming involved in matters before a federal administrative agency, even to the extent of contacting, discussing with, and representing the interests of his or her constituents before an agency. However, the Senate and the House have internal rules that govern how Members interact with administrative agencies.

\section{A. Congressional Rules and Guidance}

On January 26, 1970, the House Committee on Standards of Official Conduct issued Advisory Opinion No. 1 (“Advisory Opinion") to provide guidance for Representatives when interacting with federal administrative agencies. ${ }^{9}$ The Advisory Opinion permits a Representative to communicate with an administrative agency on any matter to:

Request information or a status report; urge prompt consideration; arrange for interviews or appointments; express judgment; call for reconsideration of an administrative response which he believes is not supported by established law, Federal regulation or legislative intent; perform any other service of a similar nature in this area

the Organization of Congress recommended that the practice of attaching legislation to appropriations bills be discontinued.").

8 Fletcher v. Peck, 10 U.S. (6 Cranch.) 87 (1810) ("The courts will not overturn the action of a legislature because of the impure motives of certain of its members.").

93 Lewis Deschler, Deschler's Precedents of the U.S. House of Representatives, ch. 12, Appendix (1970) [hereinafter Deschler's Precedents]. 
compatible with the criteria hereinafter expressed in this Advisory Opinion. 10

Additionally, the Advisory Opinion requires Representatives to uphold a standard of conduct. Specifically, Representatives must treat all constituents equally, pursue issues diligently irrespective of political or other considerations, and avoid any suggestion of either favoritism or reprisal to action taken by an agency. ${ }^{11}$

On the other hand, the Standing Rules of the Senate, Rule XLIII provides guidance for Senators when interacting with federal administrative agencies. ${ }^{12}$ Rule XLIII allows Senators to "assist constituents before federal administrative agencies by requesting information or a status report; urging prompt consideration of a matter; arranging for interviews or appointments; expressing judgments; or calling for reconsideration of an administrative response which the Member believes is not reasonably supported by statutes, regulations or considerations of public policy." 13 Senators are prohibited from advocating on behalf of constituents on the basis of contributions or services or on the promise of contributions or services. ${ }^{14}$

\section{B. Judicial Standards}

Judicial precedent can provide guidance to Members and the general public with respect to the nature and extent of allowable congressional intervention into agency adjudication and rulemaking. Under the Administrative Procedure Act ("APA"), administrative action generally falls into two categories: adjudication or rulemaking. ${ }^{15}$ Under the APA, adjudication is the "agency process for the formulation of an order." 16 Whereas, rulemaking is the "agency process for formulating, amending, or repealing a rule." 17

Adjudication and rulemaking can be either formal or informal. Formal adjudication arises in "every case of adjudication required by statute to be determined on the record after opportunity for an agency hearing." 18 Informal adjudications are not accompanied by the protections of a judicial-like trial; importantly, the APA makes no

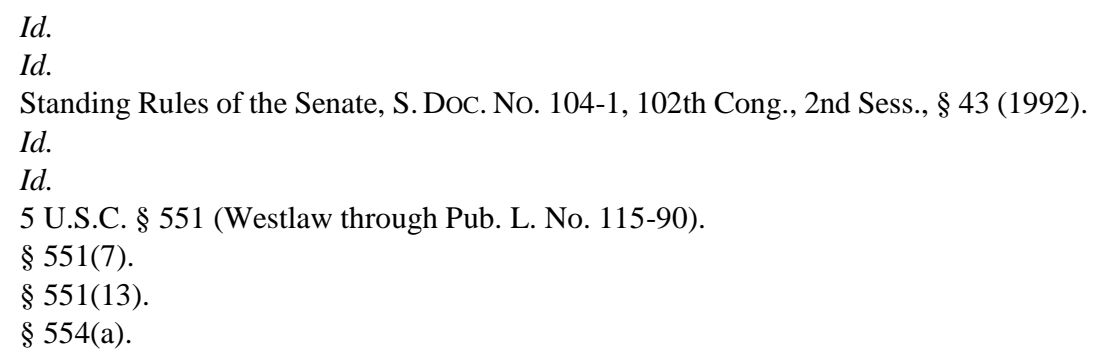


provision for informal adjudications. ${ }^{19}$ Informal rulemaking requires the administrative agency to publish a proposed rule in the Federal Register and provide "interested persons" an opportunity to participate in the rulemaking. ${ }^{20}$ Formal rulemaking must include a trial-type hearing at which a "party is entitled to present his case or defense or oral or documentary evidence, to submit rebuttal evidence, and to conduct such cross-examination as may be required for a full and true disclosure of the facts." 21

According to the Attorney General's Manual on the Administrative Act, a rulemaking proceeding is the "implementation or prescription of law or policy for the future, rather than the evaluation of a respondent's past conduct... [c]onversely, adjudication is concerned with the determination of past and present rights and liabilities." 22 Because the purpose and focus of these administrative actions are dissimilar, Congress has imposed vastly different statutory procedural requirements.

Courts have analyzed congressional intervention with respect to both adjudicatory actions and rulemaking actions; these issues will be discussed separately below.

\section{i. Adjudicatory Actions}

In Pillsbury Co. v. Fed. Trade Comm'n, ${ }^{23}$ the Senate Subcommittee on Antitrust and Monopoly held a hearing with the Federal Trade Commission ("FTC") Chairman on a key issue in an antitrust adjudication involving the Pillsbury Company which was pending before the FTC. ${ }^{24}$ During the hearing, multiple Senators, including the Committee Chair, criticized the FTC for its interpretation of the Clayton Act in a previous interlocutory order in Pillsbury's favor. ${ }^{25}$ Subsequent to the hearing, in its final order, the FTC ruled against Pillsbury, as the Committee had suggested. ${ }^{26}$ The Court of Appeals for the Fifth Circuit held that the divestiture order was invalid because the FTC's decisional process had been tainted by impermissible congressional influence. ${ }^{27}$

\footnotetext{
19 Aircraft Owners and Pilots Ass'n. v. Fed. Aviation Admin., 600 F.2d 965, 970 (D.C. Cir. 1979) ("Unlike formal adjudication ... the process did not involve trial-type, adversarial hearings.").

$20 \S 553(\mathrm{c})$.

215 U.S.C. $\$ 553(\mathrm{~d})$.

22 U.S. Dep't, of Justice, Attorney General's Manual on the Administrative Procedure Act 14 (1947).

23 Pillsbury Co. v. Fed. Trade Comm'n, 354 F.2d 952, 952 (5th Cir. 1966).

24 Id. at 953

25 Id. at 956-63.

26 Id. at 956

27 Id. at 963.
} 
Specifically, the Fifth Circuit held the Senate hearing was an "improper intrusion into the adjudicatory process of the [FTC]." 28

The Fifth Circuit reasoned that "[t]o subject an administrator to a searching examination as to how and why he reached his decision in a case still pending before him, and to criticize him for reaching the 'wrong' decision, as the Senate subcommittee did in this case, sacrifices the appearance of impartiality." 29 The Fifth Circuit concluded that it could "preserve the rights of the litigants in a case such as this without having any adverse effect upon the legitimate exercise of the investigative power of Congress. What we do is to preserve the integrity of the judicial aspect of the administrative process." 30

In Koniag v. Andrus, ${ }^{31}$ the House Subcommittee on Fisheries and Wildlife Conservation held a hearing where the Chair, Representative Dingell, voiced his displeasure with some of the initial Bureau of Indian Affairs ("BIA") eligibility determinations for several communities to receive land and money under the Alaska Native Claims Settlement Act ("ANCSA"). ${ }^{32}$ The D.C. Circuit Court held the Pillsbury decision was not applicable because none of the individuals called before the subcommittee was a decision-maker in the eligibility determinations and concluded that the hearing did not raise the appearance of impropriety. ${ }^{33}$

The D.C. Circuit found that a letter sent by Representative Dingell to the Secretary of the Interior, only two days before he determined that a number of the villages were ineligible for Federal grants, did raise the appearance of impropriety. Representative Dingell's letter requested that the Secretary of the Interior postpone his decisions on the ANCSA claims because "testimony [at the hearings] that village eligibility and Native enrollment requirements of ANCSA have been misinterpreted in the regulations and that certain villages should not have been certified as eligible for land selections under ANCSA." "34 The D.C. Circuit held that while the letter did not specify any particular villages, it compromised the appearance of the Secretary of the Interior's impartiality. ${ }^{35}$

In Peter Kiewit Sons' Co. v. U.S. Army Corps of Engineers, ${ }^{36}$ Peter

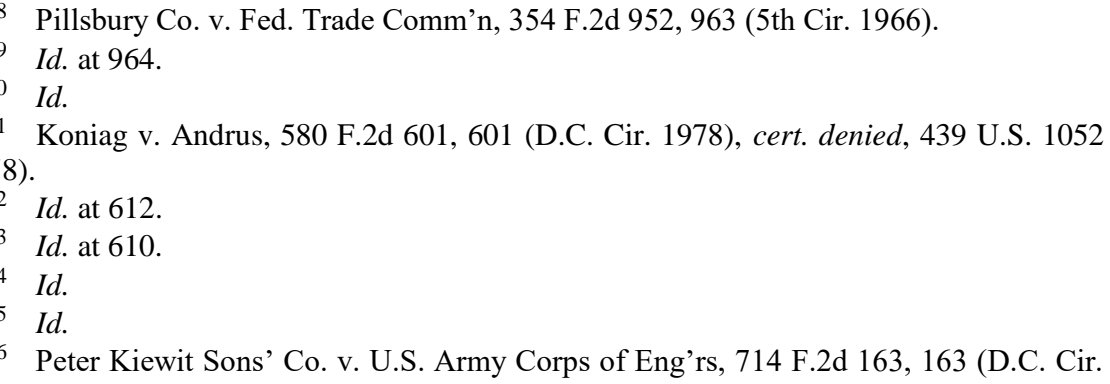


Kiewit Sons' construction company was convicted of a Sherman Act violation. Consequently, the Army Corps of Engineers, Department of the Army, and the Department of Defense, instituted debarment proceedings against the construction company. ${ }^{37}$ During an Armed Services Committee hearing, Senator Carl Levin questioned government officials about whether and why the Army Corps of Engineers had continued doing business with Peter Kiewit Sons' construction company. ${ }^{38}$ Senator Levin also wrote a letter inquiring about the status of the debarment proceedings and met with top Army officials concerning the case. ${ }^{39}$

The D.C. Circuit reasoned that a judicial or quasi-judicial proceeding could be invalidated by the appearance of bias or pressure and that "pressure on the decisionmaker alone, without proof or effect on the outcome, is sufficient to vacate a decision." 40 Moreover, the D.C. Circuit stated " $[\mathrm{t}]$ he test is whether "extraneous factors intruded into the calculus of consideration' of the individual decisionmaker." 41 The D.C. Circuit ultimately held there was no actual nor apparent congressional interference since Senator Levin never communicated directly with the ultimate decisionmaker in the debarment proceedings, nor was it shown that that official was even aware of the Senator Levin's communications. $^{42}$

In Power Auth. of N.Y. v. Fed. Energy Regulatory Comm' $n,{ }^{43}$ the Federal Energy Regulatory Commission ("FERC"), issued a number of decisions concerning the allocation of inexpensive hydroelectric power from the Niagara Power Project. ${ }^{44}$ The plaintiffs in the case argued that four Members of Congress allegedly engaged in ex parte communications with FERC in connection with the proceedings. The communications consisted of a letter from two Members of Congress from New York: Representative Jack Kemp and Representative Barber Conable to President Ronald Reagan. President Reagan forwarded the Kemp/Conable letter to the Chairman of FERC, C.M. Butler III. During

Id. at 163

Id. at 167

39 Id. at 166.

40 Id. at 169.

41 Peter Kiewit Sons' Co. v. U.S. Army Corps of Eng'rs, 714 F.2d 163, 170 (D.C. Cir. 1983) (emphasis in original) (quoting D. C. Federation of Civic Ass'ns v. Volpe, 459 F.2d 1231, 1246 (D.C. Cir. 1971)).

42 Id. 1984).

3 Power Auth. of N.Y. v. Fed. Energy Regulatory Comm'n., 743 F.2d 93, 93 (2d Cir.

$44 I d$. at 98 ("The project can be traced back to 1950, when the United States and Canada signed a treaty providing for expanded use of the Niagara River for hydropower generation."). 
a press conference attended by the four defendants, FERC officials and the public, the Legal Advisor to Chairman Butler read part of Chairman Butler's reply to the Kemp/Conable letter, which was then followed by criticism of FERC's decision by several Members of Congress. ${ }^{45}$

The Second Circuit empathized with the plaintiffs and reasoned that "[e]x parte communications by Congressmen or anyone else with a judicial or quasi-judicial body regarding a pending matter are improper and should be discouraged." 46 However, the Second Circuit found that the mere existence of such communications does not require a court or administrative body to disqualify itself and that in this case, the plaintiffs were promptly made aware of the Kemp/Conable letter and had a full opportunity to comment and respond. ${ }^{47}$

\section{ii. Non-Adjudicatory Actions}

Courts have addressed claims of undue congressional influence which are outside the context of a judicial or quasi-judicial proceeding.

In D.C. Fed'n of Civic Ass'ns v. Volpe, the plaintiffs argued that a decision to approve construction of the Three Sisters Bridge across the Potomac River by the Secretary of Transportation was tainted by extraneous pressure. ${ }^{48}$ Representative Bill Natcher, Chairman of the Subcommittee on the District of Columbia Appropriations had jurisdiction over the funding of the District of Columbia's transportation construction projects. Plaintiffs alleged that Representative Natcher threatened to deny funds for the District of Columbia's proposed subway system unless the Three Sisters Bridge project was approved and that those threats had a legal impact on the Secretary of Transportation's subsequent approval decision. ${ }^{49}$

The D.C. Circuit reasoned that the impact of the threat was sufficient, standing alone, to invalidate the Secretary of Transportation's action and held that "[e]ven if the Secretary had taken every formal step required by every applicable statutory provision, reversal would be required ... because extraneous pressure intruded into the calculus of considerations on which the Secretary's decision was based."

The D.C. Circuit opined that:

the underlying problem cannot be illuminated by a simplistic effort to force the Secretary's action into a purely judicial or

45 Id. at 109

$46 I d$. at 110

47 Id.

48 D.C. Fed'n of Civic Ass'ns v. Volpe, 459 F.2d 1231, 1235 (1971), cert. denied 405 U.S. 1030 (1972).

49 Id. at $1236-37$.

$50 \quad$ Id. at $1245-46$. 
purely legislative mold. His decision was not "judicial" in that he was not required to base it solely on a formal record established at a public hearing. At the same time, it was not purely "legislative" since Congress had already established the boundaries within which his discretion could operate. But even though his action fell between these two conceptual extremes, it is still governed by principles that we had thought elementary and beyond dispute. If, in the course of reaching his decision, Secretary Volpe took into account "considerations that Congress could not have intended to make relevant," his action proceeded from an erroneous premise and his decision cannot stand. The error would be more flagrant, of course, if the Secretary had based his decision solely on the pressures generated by Representative Natcher. But it should be clear that his action would not be immunized merely because he also considered some relevant factors. ${ }^{5}$

The D.C. Circuit's decision illustrates the difficult issues arising from judicial review of congressional interference in agency decisions, some of which are adjudicatory and some of which are legislative.

\section{iii. Rulemaking Actions}

In Sierra Club v. Costle, ${ }^{52}$ the Environmental Protection Agency ("EPA") engaged in an informal rulemaking to update its source pollution standards ("NSPS") mandated by the Clean Air Act. ${ }^{53}$ Plaintiffs argued, among other things, that the EPA engaged in post-comment meetings and received ex parte communications from Members of Congress that had caused the EPA to withdraw its support of a more stringent emission standard and was therefore unlawful and prejudicial. ${ }^{54}$

The D.C. Circuit held that if Congress wanted to forbid or limit $e x$ parte contact in cases of informal rulemaking, it would have done so. ${ }^{55}$ The Court reasoned that where

agency action resembles judicial action, where it involves formal rulemaking, adjudication, or quasi-adjudication among 'conflicting private claims to a valuable privilege,' the insulation of the decisionmaker from ex parte contacts is justified by basic notions of due process to the parties involved. But where agency action involves informal rulemaking of a policymaking sort the concept of ex parte contacts is of more questionable utility.

The Court further reasoned that "a judicially imposed blanket

51 Id. at $1247-48$.

52 Sierra Club v. Costle, 657 F.2d 298, 298 (1981).

53 Id. See 42 U.S.C. § 7411(b)(6) (Westlaw current through Pub. L. No. 115-90).

54 Sierra Club, 657 F.2d at 386-87 (finding the plaintiff objected to multiple meetings held with then Senate Majority Leader Robert Byrd).

55 Id. at 401.

$56 I d$. at 400. 
requirement that all post-comment period oral communications be docketed would ... contravene our limited powers of review, would stifle desirable experimentation in the area by Congress and the agencies, and is unnecessary for achieving the goal of an established, procedure-defined docket." 57

The Court held that it was entirely proper for Members of Congress to represent the interests of their constituents before administrative agencies engaged in informal, general policy rulemaking and that before an administrative rulemaking could be overturned simply on the grounds of political pressure, it had to be shown that "the content of the pressure on the [decisionmaker] is designed to force him to decide upon factors not made relevant by Congress in the applicable statute" and also that the determination made "must be affected by those extraneous considerations." 58

Courts have used the Sierra Club test to determine when political pressure will invalidate an agency rulemaking. However, this is a high bar to meet. For example, in Ctr. for Sci. in Pub. Interest v. Dep't of Treasury, ${ }^{59}$ the D.C. District Court stated that "[p]laintiffs cite no case, and we know of none, in which an agency decision was invalidated because the agency had received letters from congressmen arguing for a certain outcome." ${ }^{60}$ In Orangetown v. Ruckelshaus, the Southern District of New York held that "to state a cause of action for improper political influence on an administrative agency," there must be some "factual basis for a claim that: (1) the content of the pressure on the agency was designed to force it to decide upon factors not made relevant by Congress in the applicable statute; and (2) the agency's determination must have been affected by those extraneous considerations." 61

\section{Congressional Review Act}

The Administrative Procedure Act ("APA") allows Congress to review actions taken by administrative agencies. The Congressional Review Act ("CRA") requires the Government Accountability Office ("GAO") to report to Congress on whether an agency, in promulgating a major rule, has complied with the regulatory process. Under Section 801 of the APA, "[b]efore a rule can take effect, the Federal agency

57 Id. at 403

$58 I d$. at $409-10$.

59 Ctr. for Sci. in Pub. Interest v. Dep't of Treasury, 573 F. Supp. 1168, 1168 (D.D.C. 1983).

60 Id. at 1179

61 Orangetown v. Ruckelshaus, 579 F. Supp. 15, 20 (S.D.N.Y. 1984) (citing Sierra Club, 657 F.2d at 409). 
promulgating such rule shall submit to each House of the Congress and to the Comptroller General a report containing: (i) a copy of the rule; (ii) a concise general statement relating to the rule, including whether it is a major rule; and (iii) the proposed effective date of the rule."62 The submission shall include: a cost-benefit analysis (if one was prepared), the agency's actions relevant to the Regulatory Flexibility Act, the agency's actions relevant to the Unfunded Mandate Reform Act and "any other relevant information or requirements under any other Act and any relevant Executive orders." 63 GAO's report must be made to each house of Congress no later than 15 calendar days after a rule's submission or publication date. ${ }^{64}$

The CRA established expedited ("fast track") procedures by which Congress may disapprove a broad range of regulatory rules issued by federal agencies by enacting a joint resolution of disapproval. ${ }^{65}$ Under Section 801, "[a] rule shall not take effect (or continue), if the Congress enacts a joint resolution of disapproval, described under section 802." Under Section 802, Congress can pass a joint resolution stating that "Congress disapproves the rule submitted by the —— relating to - and such rule shall have no force or effect' (The blank spaces being appropriately filled in)." going into effect, it is "treated as though [it] had never taken effect." Furthermore, another very important point in the context of a fiduciary rule is that if a disapproval resolution is enacted, the rule may not take effect and the agency may issue no substantially similar rule without subsequent statutory authorization. ${ }^{6}$

The disapproval process under the CRA begins when a Member of Congress, House or Senate, submits a joint resolution of disapproval. The joint resolution is referred to the House and Senate committee with jurisdiction. ${ }^{69}$ The Congressional Research Service provides a useful illustration of the varying outcomes of CRA review: ${ }^{70}$

625 U.S.C. $\$$ 801(a)(1)(A) (Westlaw through Pub. L. No. 115-90).

$63 \S 801(\mathrm{a})(1)(\mathrm{B})(\mathrm{i})-(\mathrm{iv})$.

$64 \$ 801(\mathrm{a})(2)(\mathrm{A})$.

65 Richard Beth, CONG. RESEARCh SERV., RL31160, DisAPPROVAl OF REgUlations by Congress: Procedure Under the CONGRESSIONAL REVIEW ACT 1 (2001).

$66 \S 801(\mathrm{~b})(2)$ ("A rule that does not take effect (or does not continue) under paragraph (1) may not be reissued in substantially the same form, and a new rule that is substantially the same as such a rule may not be issued, unless the reissued or new rule is specifically authorized by a law enacted after the date of the joint resolution disapproving the original rule.").

$67 \S 802(a)$.

$68 \S 801(\mathrm{~b})$.

69 Id.

70 Richard Beth, Cong. ReSEARCh SERV., RL31160, DisapProval of REgulations by 
No Congressional Action. If neither house of Congress acts on a disapproval resolution during the original waiting period, the rule takes effect when that period expires (or later, if so provided in accordance with the Administrative Procedure Act or the terms of the rule itself).

Rejection by Either House. If either house votes to reject the disapproval resolution, the action presumably ensures that no disapproval resolution will pass both chambers. At that point the waiting period is vitiated, and the rule may take effect immediately (or later, if so required by the Administrative Procedure Act or the rule itself).

Passage by Both Houses; No Veto. If both houses pass the disapproval resolution and the President does not veto it, the resolution becomes law, and the rule becomes "of no force and effect"' (whether or not the waiting period has expired).

Passage; Veto; No Attempt to Override. If both houses pass the disapproval resolution and the President vetoes it, the receipt by Congress of the veto message triggers the new waiting period of 30 days of session. If a vote on overriding the veto occurs in neither house, or in only one house, during this new waiting period, the rule takes effect when the 30 days of session expire (or later, if so required by other authorities). Passage; Veto Sustained by Either House. If either house votes to sustain the veto, Congress can no longer override. At that point the additional 30-day waiting period is vitiated, and the rule may take effect immediately (or later, if so required by other authorities).

Passage; Veto Overridden. If both houses override the veto, the disapproval resolution becomes law, so that the rule becomes "of no force and effect.",

It is important to note that "the [CRA] provides no expedited procedure for overriding a veto. Consideration of veto messages is generally considered privileged in both chambers pursuant to the requirements of the Constitution. The procedures of neither house, however, require a vote on whether to override. In the Senate, an attempt to reach such a vote might be delayed or blocked by filibuster. In other respects, the normal procedures of each house probably would suffice to allow a majority that wished an override vote to secure one."72

However, even though Congress has this power of review, it is rarely used. In 2006, the GAO found from 1996 to 2006, Members of Congress introduced only thirty-seven CRA disapproval resolutions, and only one of those was ultimately approved. ${ }^{73}$ This number is infinitesimal (less than one percent) compared to the total number of rules proposed by agencies in that same time period, which the GAO reported as 41,828

\footnotetext{
CONGRESS: Procedure Under THE CONGRESSIONAL REVIEW ACT 8-9 (2001).

$71 \quad I d$.

72 Id. at 14.

73 U.S. Gov't Accountability OfFice, GAO-06-601T, PersPectives on 10 YeARs of Congressional Review Act IMPLEMENTATION, 1, 3 (2006).
} 
major and non-major rules. ${ }^{74}$

\section{EfFectuating Policy Change Through Substantive APPROPRIATIONS RIDERS}

Congress' power of the purse is a powerful tool and the appropriations process is "one of the most important authorities allocated to Congress." " Courts have stated that "constitutional structure would collapse, and the role of the House would be meaningless, if the Executive could circumvent the appropriations process and spend funds however it pleases." 76 However, while Congress holds the purse strings, it cannot intrude on the Executive's authority of enforcing laws. ${ }^{77}$ Therefore, it is important to note that this Article focuses on substantive limitations placed on executive agencies in the appropriations process, rather than constitutionally-acceptable funding decisions made by Congress. $^{78}$

\section{A. Congressional Rules and Guidance}

The Senate and House have internal rules that encourage the separation of money and policy decisions. Specifically, legislating through appropriations riders violates Senate and House ruleslegislative provisions typically may not be included in appropriations measures. ${ }^{79}$ It is important to note that these rules only apply to general appropriations bills, ${ }^{80}$ they do not apply to continuing resolutions. ${ }^{81}$

In the House, House Rule XXI prohibits legislative provisions from

74 Id. at 4.

75 The Federalist No. 58 (James Madison) ("This power over the purse may, in fact, be regarded as the most complete and effectual weapon with which any constitution can arm the immediate representatives of the people").

76 United States House of Representatives v. Burwell, 130 F.Supp.3d 53, 73 (D.D.C. 2015).

77 U.S. CONST. art. II, $\S \S 1-2$.

78 These would be limitations that restrict the amount or availability of funds without changing the existing law.

79 Deschler's Precedents, vol. 8, chapter 26, § 24 ("Generally, language in an appropriation bill proposing to repeal existing law is legislation and not in order. Similarly, an amendment in the form of a limitation but construing or interpreting existing law is legislation and not in order on an appropriation bill.").

80 Jessica Tollestrup, CONG. Research SERV., The CONGressional ApPropriations PROCESS: AN INTRODUCTION 13 (2014) ("The appropriations process assumes the consideration of 12 regular appropriations measures annually. Each House and Senate appropriations subcommittee has jurisdiction over one regular bill").

81 Id. at 14 ("Traditionally, continuing appropriations have been used to maintain temporary funding for agencies and programs until the regular bills are enacted. Such appropriations continuing funding are usually provided in a joint resolution, hence the term continuing resolution (or CR)). 
being reported in general appropriation bills and amendments to appropriation bills containing language that would alter existing laws are also prohibited. $^{82}$ Clause 5 of House Rule XXI also bars legislative language in conference reports that accompany appropriations acts. ${ }^{83} \mathrm{In}$ the Senate, Senate Rule XVI restricts legislative language not contained within existing law from being added via amendment to a general appropriations bill unless it is determined to be made to carry out the provisions of some existing law. ${ }^{84}$ These rules are enforced on the House and Senate floor by points of order. ${ }^{85}$ It is important to note that since House and Senate rules are not self-enforcing, a point of order must be made against a legislative provisions, and without this action, the provision could be considered and adopted. ${ }^{86}$

Members of Congress, while being subject to these restrictions on the use of legislative language in appropriations bills, have procedures to circumvent these rules. First, the House may "grant unanimous consent that points of order be waived against all of the provisions contained in an appropriation bill." 87 Second, the House may "adopt a resolution waiving points of order against a section of an appropriation bill which contains legislative provisions in violation of Clause 2 of Rule XXI." 88

\section{Policy Riders In ApPropriations MEAsures ARE UNCONSTITUTIONAL}

Under the Constitution, the President shall ensure that laws are faithfully executed" ${ }^{89}$ and the "executive Power shall be vested in a

82 Rules of the U.S. House of Representatives, H.R. Doc. No 113-181, 113th Cong., 2nd Sess. $§ 1034-35$ (2015).

83 Id. at $§ 1064$.

84 Standing Rules of the Senate, S. Doc. No. 113-1, 113th Cong., 1st Sess., § 1 (2015).

85 James V. Saturno, CONG. Research SERV., Points OF Order IN THE Congressional Budget Process 1-2 (2015) ("Points of order are typically in the form of a provision stating that "it shall not be in order" for the House or Senate to take a specified action or consider certain legislation. When a point of order is sustained against consideration of some matter, the effect is that the matter in question falls.").

86 U.S. House of Reps. Comm. On Rules, Budget Act Points of Order Applicable in the House of Representatives, available at http://archives.democrats.rules.house.gov/POP/

budget_points.htm ("Points of order are not self-enforcing, but rather are only brought into play when a member raises a "point of order" against a specific Congressional action prior to or during its consideration.")

87 Deschler's Precedents, vol. 8, chapter 26, § 3.1. ("Unanimous consent is “"[a] proposal that all members (of a chamber or committee) agree to set aside one or more chamber or committee rules to take some action otherwise not in order. If any member objects to such a request, it is not agreed to.").

88 Deschler's Precedents, vol. 8, chapter 26, § 3.2.

89 U.S. CONST. art. II, $\S 3$. 
President of the United States of America." 90 This power has been affirmed since the beginning of our Democracy. For example, James Madison stated that "if any power whatsoever is in its nature Executive, it is the power of appointing, overseeing, and controlling those who execute the laws." 91

For the legislative branch, the Constitution does not differentiate Congress' authority to appropriate funds from its other legislative powers. However, this Article contends that while Congress has authority to fund, or not to fund, the government, it has no authority to direct administrative agencies' execution of the law and that any action by Congress in that respect would be unconstitutional. The Supreme Court has held that "Congress can thereafter control the execution of [a law's] enactment only indirectly - by passing new legislation." ${ }^{92}$ In effect, Congress cannot direct the interpretation of laws it has passed without amending the underlying statute. This is plain in the wording of the Constitution, where it separates Congress' authority to create law from the executive branch's ability to enforce it. ${ }^{93}$

\section{A. Separation of Powers}

It is important to note that courts have consistently upheld agencies' power to carry out legislative policies embodied in federal statutes, i.e., create rules to implement statutory law. The Supreme Court has long held that courts are not permitted "to probe the mental processes" of administrators ${ }^{94}$ and that "the integrity of the administrative process must be ... respected." 95 In Myers v. United States ${ }^{96}$ the Supreme Court held that "there may be duties of a quasi-judicial character imposed on executive officers and members of executive tribunals whose decisions after hearing affect interests of individuals." ${ }^{97}$ In Humphrey's Ex'r $v$. United States,${ }^{98}$ the Supreme Court held that:

Federal Trade Commission is an administrative body created by Congress to carry into effect legislative policies embodied in the statute in accordance with the legislative standard

\footnotetext{
90 U.S. CONST. art. II, $\S 1$, cl. 1.

911 AnNals of Cong. 463 (1789) (Joseph Gales ed., 1834) (statement of Rep. James Madison) (emphasis added).

92 Bowsher v. Synar, 478 U.S. 714, 733 (1986).

93 U.S. CONST. art. I, § 8, cl. 18 (Congress shall have the power to "make all Laws which shall be necessary and proper for carrying into Execution the foregoing Powers.") (emphasis added).

94 Morgan v. United States, 304 U.S. 1, 18 (1938).

95 Morgan v. United States, 313 U.S. 409, 422 (1941).

96 Myers v. United States 272 U.S. 52, 52 (1926).

97 Id. at 135 .

98 Humphrey's Ex'r v. United States, 295 U.S. 602, 602 (1935).
} 
therein prescribed, and to perform other specified duties as a legislative or as a judicial aid... In administering the provisions of the statute in respect of 'unfair methods of competition - that is to say in filling in and administering the details embodied by that general standard - the commission acts in part quasi-legislatively and in part quasi-judicially. ${ }^{99}$

Courts have consistently upheld agency rulemakings based upon a delegation of authority from Congress. In Mistretta v. United States ${ }^{100}$, the Supreme Court held that Congress could not do its job absent an ability to delegate power to executive agencies. ${ }^{101}$ The Court deemed it "constitutionally sufficient if Congress clearly delineates the general policy, the public agency which is to apply it, and the boundaries of this delegated authority." 102 In Northwest Forest Resource v. Pilchuck Audubon Soc' $y,{ }^{103}$ the Ninth Circuit held that " $[\mathrm{t}]$ he power of the Secretaries to administer the Congressionally created program 'necessarily requires the formulation of policy and the making of rules to fill any gap left, implicitly or explicitly, by Congress." 104 This delegation authority is even more powerful with respect to certain agencies. For example, in Bob Jones University v. United States, ${ }^{105}$ the Supreme Court held that "ever since the inception of the Tax Code, Congress has seen fit to vest in those administering the tax laws very broad authority to interpret those laws." 106

Courts have also repeatedly affirmed that Congress' power is bound by the Constitution. In Buckley v. Valeo ${ }^{107}$ the Supreme Court held that "Congress' power. . .is inevitably bounded by the express language" of the Constitution. ${ }^{108}$ In Loving v. United States, ${ }^{109}$ the Supreme Court held that one branch of government could not "impair another in the performance of its constitutional duties." "In INS v. Chadha, ${ }^{111}$ the Supreme Court held that a one-house legislative veto was unconstitutional because "each House of Congress retained the power to reverse a decision Congress had expressly authorized the Attorney

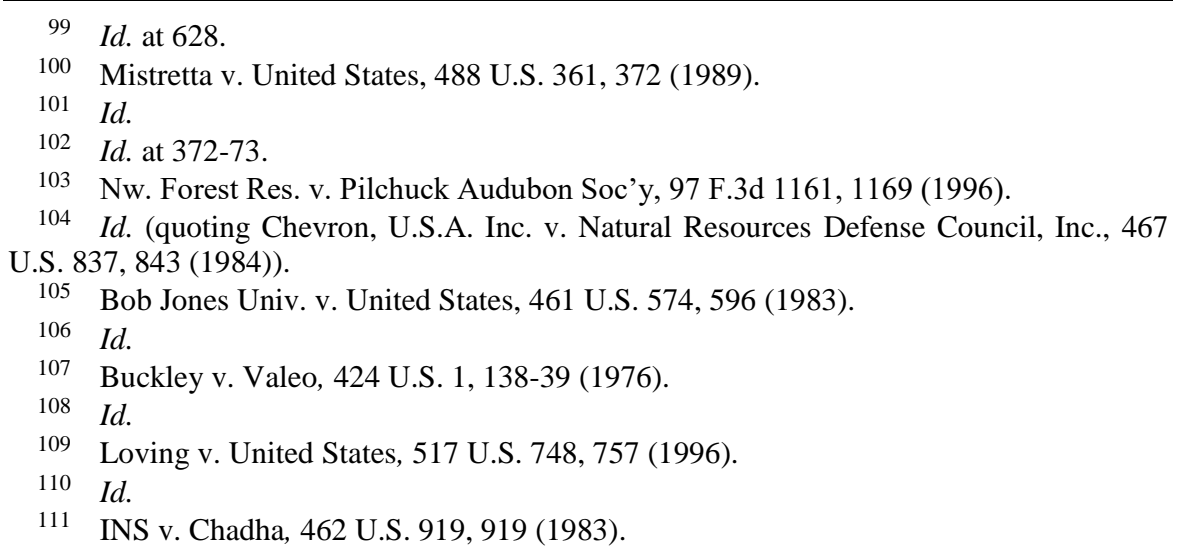


General to make."112 The Court reasoned that:

[d]isagreement with the Attorney General's decision on Chadha's deportation - that is, Congress' decision to deport Chadha-no less than Congress' original choice to delegate to the Attorney General the authority to make that decision, involves determinations of policy that Congress can implement in only one way; bicameral passage followed by presentment to the President. Congress must abide by its delegation of authority until that delegation is legislatively altered or revoked.

In Fed. Election Comm'n v. NRA Political Victory Fund, ${ }^{114}$ the Supreme Court held that while Congress may inform itself of how legislation is being implemented through legislative oversight and investigation, Congress is forbidden from intervening in the decision making necessary to execute the law. ${ }^{115}$ In Bowsher v. Synar, the Supreme Court held that " $[\mathrm{t}] \mathrm{h}$. Constitution does not contemplate an active role for Congress in the supervision of officers charged with the execution of the laws it enacts."116 The Supreme Court reasoned that: to permit an officer controlled by Congress to execute the laws would be, in essence, to permit a congressional veto. Congress could simply remove, or threaten to remove, an officer for executing the laws in any fashion found to be unsatisfactory to Congress. This kind of congressional control over the execution of the laws, Chadha makes clear, is constitutionally impermissible.

There is limited precedent that speaks directly to the constitutionality of substantive policy riders in appropriations bills. In United States v. Dickerson, ${ }^{118}$ the Supreme Court stated that there was no doubt that Congress could use the appropriation process to amend an underlying statute. ${ }^{119}$ In Tennessee Valley Auth. v. Hill, ${ }^{120}$ the Supreme Court

112 Id.

113 Id. at 954-55. See also Constitutionality of Congress' Disapproval of Agency Regulations by Resolutions Not Presented to the President, 4A OP. O.L.C. 21, 27 (1980) (opinion of the Attorney General) ("[O]nce a function has been delegated to the executive branch, it must be performed there, and cannot be subjected to continuing congressional control except through the constitutional process of enacting new legislation.").

114 Fed. Election Comm'n v. NRA Political Victory Fund, 6 F.3d 821, 827 (D.C. Cir. 1993), cert. dismissed, 513 U.S. 88 (1994)

115 Id. (citing Metropolitan Washington Airports Auth. v. Citizens for Abatement of Aircraft Noise, Inc., 115 L. Ed. 2d 236, 236 (1991) ("The Court recalled that the Framers recognized that 'power is of an encroaching nature,' The Federalist No. 48, at 332 (J. Madison) (J. Cooke ed. 1961), and therefore the Constitution imposes a structural ban on legislative intrusions into other governmental functions.").

116 Bowsher v. Synar, 478 U.S. 714, 722 (1986).

117 Id. at 726

118 United States v. Dickerson, 301 U.S. 554, 555 (1940).

119 Id.

120 Tennessee Valley Auth. v. Hill, 437 U.S. 153, 190 (1978). 
recognized

both substantive enactments and appropriations measures are 'Acts of Congress,' but the latter have the limited and specific purpose of providing funds for authorized programs. When voting on appropriations measures, legislators are entitled to operate under the assumption that the funds will be devoted to purposes which are lawful and not for any purpose forbidden. Without such an assurance, every appropriations measure would be pregnant with prospects of altering substantive legislation, repealing by implication any prior statute which might prohibit the expenditure. Not only would this lead to the absurd result of requiring Members to review exhaustively the background of every authorization before voting on an appropriation, but it would flout the very rules the Congress carefully adopted to avoid this need.

In Preterm v. Dukakis, ${ }^{122}$ a case looking at exclusive state financing of abortions and the Medicaid Act, the First Circuit was "persuaded that Congress realized that it was using the unusual and frowned upon device of legislating via an appropriations measure to accomplish a substantive result." ${ }^{123}$ In Doe v. Busbee, ${ }^{124}$ the Northern District of Georgia found a "recognized and settled policy of Congress against legislating in an appropriations context." ${ }^{125}$ In Alliance for the Wild Rockies v. Salazar, ${ }^{126}$ the United States District Court for the District of Montana opined that "[i]nserting environmental policy changes into appropriations bills may be politically expedient, but it transgresses the process envisioned by the Constitution by avoiding the very debate on issues of political importance said to provide legitimacy." 127

In a contrary holding, in Robertson v. Seattle Audubon Soc' $y,{ }^{128}$ the Supreme Court held that "although repeals by implication are especially disfavored in the appropriations context, Congress nonetheless may amend substantive law in an appropriations statute, as long as it does so clearly." 129 However, with respect to administrative regulations that implement statutory law, the Supreme Court has stated that "Congress must abide by its delegation of authority until that delegation is altered or revoked." 130 Importantly, the Supreme Court in Buckley affirmed that the enforcement power of the executive branch includes the power to

$121 \quad I d$.

122 Preterm v. Dukakis, 591 F.2d 121, 131 (1st Cir. 1979).

123 Id.

124 Doe v. Busbee, 471 F. Supp. 1326, 1326 (N.D. Ga. 1979).

125 Id.

126 All. for the Wild Rockies v. Salazar, 800 F. Supp. 2d 1123, 1125 (D. Mont. 2011).

127 Id.

128 Robertson v. Seattle Audubon Soc'y, 503 U.S. 429, 440 (1992) (citations omitted).

129 Id

130 Morrison v. Olson, 487 U.S. 654, 657 (1988). 
implement the law. ${ }^{131}$ In Bowsher, the Supreme Court held that "[i]nterpreting a law enacted by Congress to implement the legislative mandate is the very essence of 'execution' of the law." 132

This Article advocates that the approach taken by the courts in TVA, Preterm, Doe, and Alliance is the correct approach, and it argues that rather than using the appropriations process to amend an underlying statute, Congress may have the authority to mandate a certain interpretation of the statutory laws it has created. This factual situation is distinguishable from Robertson, in which the Court found that Congress was making changes in law, not findings or results under old law, and would instead rely on Olson, which found that Congress's delegation stands until it is revoked, and Bowsher and Buckley, which found that the executive's authority to execute the law includes the power to implement the law through regulation.

These cases illustrate that Congress potentially violates the separation of powers under the Constitution when it directs executive and independent agencies to interpret statutes in a certain way.

\section{B. Presentment Clause}

The use of substantive policy riders in the appropriations process violates both the letter and the spirit of the Presentment Clause of the Constitution. ${ }^{133}$ In TVA, the Supreme Court held that the use of appropriation bills to make substantive changes in legislation would "lead to the absurd result of requiring Congress to review exhaustively the background of every authorization before voting on an appropriation."134

In Clinton v. City of New York, the Supreme Court held that the use of a "line item veto" by President Bill Clinton was unconstitutional. ${ }^{135}$ The Supreme Court reasoned that, among other things, if the line item veto had been valid, then it would have authorized the President to create a law whose text was not voted on by either house of Congress or

131 Buckley v. Valeo, 424 U.S. 1, 140-41 (1976).

132 Bowsher v. Synar, 478 U.S. 714, 733 (1986).

133 U.S. Const. art. I, § 7, cl. 2 ("Every bill which shall have passed the House of Representatives and the Senate, shall, before it become a law, be presented to the President of the United States; if he approve he shall sign it, but if not he shall return it, with his objections to that House in which it shall have originated, who shall enter the objections at large on their journal, and proceed to reconsider it. If after such reconsideration two thirds of that House shall agree to pass the bill, it shall be sent, together with the objections, to the other House, by which it shall likewise be reconsidered, and if approved by two thirds of that House, it shall become a law").

134 Tennessee Valley Auth. v. Hill, 437 U.S. 153, 190 (1978).

135 Clinton v. City of New York, 524 U.S. 417, 449 (1998). 
presented to the President for signature."136 This reasoning is important; riders to appropriation bills undermine "deliberative lawmaking, which requires legislators to (1) make explicit policy choices, (2) employ procedures that limit arbitrary action, and (3) produce a record that is subject to meaningful judicial review." 137 Substantive changes to existing legislation through appropriation riders do not receive adequate attention and are generally introduced late in the process, with little debate. $^{138}$

This Article contends that since the appropriation riders do not go through the normally-required legislative procedures, often without debate and obscured in voluminous budget documents, the riders would authorize the President to create a law whose text was not subject to a deliberative vote in Congress and a law that was not presented to the President for his or her signature. In other words, the process removes the President's veto authority by attaching riders to must-pass spending bills. As a result, this process violates the spirit, if not the letter, of the Constitution and delegitimizes the legislative process. ${ }^{139}$

\section{Due Process}

Policy riders that force administrative action have the potential to violate the due process clause of the Constitution. The Constitution states that "[n]o person shall . . . be deprived of life, liberty, or property, without due process of law; nor shall private property be taken for public use, without just compensation." 140 The Supreme Court has reaffirmed that "[c]ontract rights are a form of property and as such may be taken ... provided that just compensation is paid" 141 and "[v]alid contracts are property, whether the obligor be a private individual, a municipality, a State, or the United States." 142 It is important to note that the Contracts Clause of the Constitution would not be applicable, since it only applies to states, not the federal government. ${ }^{143}$

\footnotetext{
136 Id. at 448.

137 Edward A. Fitzgerald, Alliance for Wild Rockies v. Salazar: Congress Behaving Badly, 25 VilL. ENVTL. L.J. 351, 394 (2014).

138 Id. at 395.

139 See All. for the Wild Rockies, 800 F. Supp. 2d at1123.

140 U.S. CONST. art. V.

141 U.S. Trust Co. v. New Jersey, 431 U.S. 1, 19 n.16 (1977).

142 Lynch v. U.S., 292 U.S. 571, 579 (1934).

143 U.S. Const. art. I, § 10 ("No State shall. . .pass any. . .Law impairing the Obligation of Contracts."). Pension Benefit Guaranty Corp. v. R.A. Gray \& Co., 467 U.S. 717, 733 (1984) ("The Supreme Court has also stated that "we have contrasted the limitations imposed on States by the Contract Clause with the less searching standards imposed on economic legislation by the Due Process Clause").
} 
The recent Department of Labor ("DOL") "fiduciary" rulemaking, ${ }^{144}$ is a notable example of how Congressional riders could potentially violate the Due Process Clause of the Constitution. The DOL rule requires firms and advisors to enter into "Best Interest Contracts" ("BICs") with their clients. ${ }^{145}$ This requirement becomes applicable on January $1,2018 .{ }^{146}$ If Congress uses a policy rider to delay or repeal the DOL rule before this date, due process concerns will likely not arise. However, Congress could act unconstitutionally by delaying or repealing the rule after January 1, 2018. ${ }^{147}$

The Supreme Court has stated that "Congress has considerable leeway to fashion economic legislation, including the power to affect contractual commitments between private parties." "Additionally, it is "well established that legislative Acts adjusting the burdens and benefits of economic life come to the Court with a presumption of constitutionality, and that the burden is on one complaining of a due process violation to establish that the legislature has acted in an arbitrary and irrational way." 149

In a landmark decision, Omnia Commercial Co. v. United States, ${ }^{150}$ the Supreme Court held the federal government had a broadly applicable defense against takings actions based on interference with existing private contracts. Specifically, the Supreme Court found that government actions that only incidentally interfere with performance of private contracts - rather than targeting them directly - constitute a "frustration," not a taking, of those contract rights. ${ }^{151}$

While the Omnia decision is broad, it does have its limitations. Most importantly, Omnia does not apply when legislation expressly "targets" an existing contract right-rather than affecting contract rights only

144 Definition of the Term "Fiduciary"; Conflict of Interest Rule-Retirement Investment Advice, 81 Fed. Reg. 20946 (Apr. 8, 2016) (29 C.F.R. Pts. 2509, 2510, 2550); Best Interest Contract Exemption, 81 Fed. Reg. 21002 (Apr. 8, 2016) (29 C.F.R. Pt. 2550).

145 Best Interest Contract Exemption; Correction, 81 Fed. Reg. 44773 (Jul. 11, 2016) (29 CFR Pt. 2550).

146 Best Interest Contract Exemption; Correction, 81 Fed. Reg. 44773 (Jul. 11, 2016) (29 CFR Pt. 2550).

147 Pension Benefit Guar. Corp. v. R. A. Gray \& Co., 467 U.S. 717, 730 ("It does not follow ... that what Congress can legislate prospectively it can legislate retrospectively. The retroactive aspects of legislation, as well as the prospective aspects, must meet the test of due process, and the justifications for the latter may not suffice for the former.") (quoting Usery v. Turner Elkhorn Mining Co., 428 U.S. 1, 16-17 (1976)).

148 E. Enterprises v. Apfel, 524 U.S. 498, 528 (1998).

149 Concrete Pipe \& Prods. v. Constr. Laborers Pension Tr., 508 U.S. 602, 637 (1993) (quoting Williamson v. Lee Optical Co., 348 U.S. 483, 487-88 (1955)).

150 Omnia Commercial Co. v. United States, 261 U.S. 502, 510 (1923).

151 Id. at 513 . 
incidentally. ${ }^{152}$ In these cases, the Supreme Court uses the test described in Penn Central Transp. Co. v. New York City. ${ }^{153}$ Accordingly, under Penn Central Transp., courts apply the following test: (1) the economic impact of the government action on the property owner; (2) the degree of interference with the property owner's investment-backed expectations; and (3) the "character" of the government action. ${ }^{154}$

This Article contends that the use of a policy rider to delay or repeal the DOL rule, after the January 1, 2018 applicability date, would violate the Due Process Clause of the Constitution by specifically targeting the BIC contracts entered into by advisors and their clients.

First, the action would directly target and nullify the BIC contracts. In a Senate Committee on Homeland Security and Government Affairs report, Senator Ron Johnson cites experts and states that "[t]o take advantage of the BIC exemption, the investor and advisor must sign a contract acknowledging fiduciary status. The advisor must act in the best interest of the client and must make numerous disclosures to the client and to the Labor Department. Experts contend that the BIC exemption is unworkable and will increase the cost of investment advice and services and will, consequently, decrease access to investment services for small investors." 155

In September 2015, during a hearing before the House Subcommittee on Oversight of the Committee on Ways and Means, Chairman Peter Roskam stated:

$[\mathrm{u}]$ nder the proposed fiduciary rule, commission-based plans would be virtually eliminated. There is an exception if the advisors and their clients enter into a so-called best-interest contract, but this . . . creates a legal and financial liability for investment advisors that will have serious consequences on access to competent and affordable financial advice. ${ }^{15}$

In the same hearing, Representative Joseph Crowley stated that he had been informed that "there ... [are] too many compliance burdens in the

152 Cienega Gardens v. United States, 331 F.3d 1319, 1335 (Fed. Cir. 2003) (“Omnia refers to legislation targeted at some public benefit, which incidentally affects contract rights, not. . .legislation aimed at the contract rights themselves in order to nullify them.").

153 Penn Cent. Transp. Co. v. New York, 438 U.S. 104, 124 (1978).

154 Id. at 124.

155 Senator Ron Johnson, The Labor Department's Fiduciary Rule: How a Flawed Process Could Hurt Retirement Savers, A Majority Staff Report of the Senate Committee on Homeland Security and Governmental AfFairs, Feb. 24, 2016, at 29, available at https://www.hsgac.senate.gov/download/the-labor-departments-fiduciary-rulehow-a-flawed-process-could-hurt-retirement-savers.

156 Hearing on the Department of Labor's Proposed Fiduciary Rule, Before the $H$. Subcomm. on Oversight of the Committee on Ways and Means, 114th Cong. 5 (2015) (opening statement by Chairman Peter Roskam), available at https://waysandmeans.house.gov/wpcontent/uploads/2016/10/20150930OS-Transcript.pdf. 
proposed BIC exemption." "157 In the April 2016 disapproval motion filed by Congress under the CRA, Members of Congress contended that " $\mathrm{t}] \mathrm{he}$ BIC exemption was widely panned as [] unworkable." 158

Based on these on the record statements, it will be difficult for Members of Congress to fashion a policy rider that would repeal the DOL rule without targeting the BIC contract. Once it is established that a policy rider repealing the rule would target the BIC contracts, the Penn Central test must be applied.

First, the economic impact on the property owners, specifically holders of Individual Retirement Accounts ("IRA") under the BIC, will be enormous. Assets in IRAs totaled $\$ 7.8$ trillion at the end of the third quarter of 2016. ${ }^{159}$ In its Regulatory Impact Analysis ("RIA"), the DOL found that the rule may result in a gain between $\$ 40$ billion and $\$ 44$ billion over 10 years for IRA investors. ${ }^{160}$

Second, the degree of interference is substantial. Repealing the rule would effectively revert retirement investors' back to their pre-enactment financial position, where the DOL found that for mutual fund investments in IRAs alone, investors would lose between \$210 billion and \$430 billion over 10 years, and between $\$ 500$ billion and $\$ 1$ trillion over 20 years as a result of conflicted advice. According to the DOL's analysis, an investor who moves money out of a 401(k) plan and into an IRA based on conflicted advice can expect to lose twelve to twenty-four percent of the value of his or her savings over 30 years. ${ }^{161}$

Third, Congress's use of a policy rider in an appropriations bill to repeal the DOL rule would be an arbitrary and irrational action. It is "well established that ... the burden is on one complaining of a due process violation to establish that the legislature has acted in an arbitrary and irrational way." "162 The DOL provided an exhaustive (almost 400-page) impact analysis based upon a wealth of academic and empirical evidence. ${ }^{163}$ For Congress to simply repeal the rule without providing a

157 Id. at 33.

158 Disapproving The Rule Submitted By The Department Of Labor Relating To The Definition Of The Term "Fiduciary," H.R.J. Res. 88, 114th Cong. (2016).

159 ICI, "Retirement Assets Total \$25.0 Trillion in Third Quarter 2016," available at https://www.ici.org/ research/stats/retirement/ret_17_q3 (last visited Dec. 27, 2017).

160 U.S. Dep't of Labor, Fiduciary Investment Advice: Regulatory Impact Analysis (Apr. 14, 2015), available at https:/www.dol.gov/sites/default/files/ebsa/laws-and-regulations/ rules-and-regulations/proposed-regulations/1210-AB32-2/conflictsofinterestria.pdf (last visited Dec. 27, 2017).

161 Id.

162 Concrete Pipe \& Prods. v. Constr. Laborers Pension Tr., 508 U.S. 602,637 (1993) (quoting Williamson v. Lee Optical Co., 348 U.S. 483, 487-88 (1955)).

163 U.S. Dep't of Labor, supra note 160. 
comprehensive analysis of its own, illustrating why the rule should be repealed, would be an arbitrary and irrational act.

Based on this analysis, while the courts grant considerable deference to the legislature for due process cases, there is evidence that a repeal of the DOL rule by a policy rider in an appropriation bill-which would likely receive little, if any, debate, and would not be accompanied by any type of empirical research supporting repeal-would effectively violate the due process rights of IRA holders who have BIC contracts.

\section{Policy Riders Are Not An Effective Policymaking Vehicle}

The use of substantive policy riders in the appropriations process is an ineffective method to create policy for regulatory agencies.

\section{A. Congressional Disapproval}

While Congress routinely waives its rules to allow substantive legislation to be attached to appropriation bills, Congress has consistently warned against these measures. In 1946, the Joint Committee on the Organization of Congress ("JCOC") recommended that the practice of attaching legislation to appropriation bills be discontinued. ${ }^{164}$ The JCOC report stated:

[t]he practice of attaching legislation to appropriation bills is often destructive of orderly procedure ... Sometimes they contradict action previously approved in carefully considered legislation. In most cases such legislation is adopted under the parliamentary guise of 'limiting provisos,' avoiding points of order that would be raised against them by purporting to restrict the spending of Government funds.

The JCOC report went on to state that these practices, "when used for purposes other than to effect real economies, should be prohibited by a tightening of the rules" otherwise the "regular jurisdiction of the standing committees ... will continue to be impinged upon by the appropriating committees. Much added work in Government departments and by private attorneys is caused by attaching legislative riders on appropriation bills." 166

\section{B. Executive Disapproval}

The executive branch, under both Republican and Democratic administrations, has long worried about the unconstitutional Congressional encroachment. In 1880, President Rutherford B. Hayes stated, "I am firmly convinced that appropriation bills ought not to

164 S. REP. No. 79-1011, at 23 (1946).

165 Id. at 23-24.

166 Id. 
contain any legislation not relevant to the application or expenditure of the money thereby appropriated, and that by a strict adherence to this principle an important and much-needed reform will be accomplished."167 President Hayes emphasized that policy riders "invite[] attacks upon the independence and constitutional powers of the Executive by providing an easy and effective way of constraining Executive discretion." 168 In 1945, President Harry Truman stated that "Congress has acted contrary to its own declared position, and has attempted to effect a far-reaching change in the organization of the Executive Branch" and that substantive legislation "should not be dealt with as riders to appropriations bills." 169 In 1987, President Ronald Reagan, when signing an appropriation bill, stated:

Article II of the Constitution assigns responsibility for executing the law to the President. While the Congress is empowered to enact new or different laws, it may not indirectly interpret and implement existing laws, which is an essential function allocated by the Constitution to the executive branch. If the Congress disagrees with a statutory interpretation advanced by the executive branch - or with the efforts of the executive branch to defend or prosecute judicial action based on that interpretation-the Congress may, of course, amend the underlying statute. The use of an appropriations bill for this purpose, however, is inconsistent with the constitutional scheme of separation of powers. ${ }^{170}$

\section{Normal Legislative Process Encourages Informed Deliberation}

The normal legislative process provides ample opportunity for Members of Congress to consider the subject matter of the proposed bill, as well as public scrutiny, in the form of committee research and recommendations, floor debates, and conference reports. ${ }^{171}$ In contrast, appropriation riders receive very little, if any, deliberation and

167 President Rutherford B. Hayes, Veto of Appropriations Bill (May 4, 1880) (transcript available at http://www. rbhayes.org/clientuploads/RBHSpeeches/speechrbh514.htm).

168 Id.

169 President Harry Truman, Veto of Bill Making Supplemental Appropriations for the Federal Security Agency (Jul. 15, 1948) (transcript available at https://trumanlibrary.org/ publicpapers/viewpapers.php?pid=1681) (Truman also stated that the "legislation, which is of such paramount importance to the interests of millions of wage earners and employers, and which is plainly substantive in nature, was passed by the Congress entirely without reference to or hearings by the legislative committees concerned with such matters. Neither the House Committee on Education and Labor nor the Senate Committee on Labor and Public Welfare was given an opportunity to consider the measure. Instead it was conceived by a subcommittee on appropriations and tacked onto an appropriations bill.").

170 President Ronald Reagan, Statement on Signing H.R. 1827 into Law (Jul. 11, 1987) (transcript available at http://www.presidency.ucsb.edu/ws/?pid=34542) (emphasis added).

171 The Legislative Process, CONGRESS.ORG, http://congress.org/advocacy-101/thelegislative-process/ (last visited Dec. 27, 2017). 
[Vol. 42:1

specifically prevent any public involvement or informed legislative debate. Policy riders are often attached to must-pass spending legislation, which forces the President to accept the riders or face the possibility of a government shut-down.

Significantly, there is a substantial difference between the normal legislative process and the introduction of a policy rider into an appropriation bill or continuing resolution. In the chart below, the lack of deliberation and transparency often seen when policy riders are attached to must-pass spending legislation, is illustrated:

\begin{tabular}{|l|l|}
\hline Normal Legislative Process & Policy Rider Process \\
\hline Bill Drafted & Policy Rider Drafted \\
\hline $\begin{array}{l}\text { Bill Referred to Committee and } \\
\text { Subcommittee for Study and } \\
\text { Hearings }\end{array}$ & \\
\hline $\begin{array}{l}\text { Bill "Marked Up" by } \\
\text { Subcommittee }\end{array}$ & \\
\hline Subcommittee Vote & \\
\hline $\begin{array}{l}\text { Bill Reviewed by Full Committee } \\
\text { (Further Study and Hearings } \\
\text { Possible) }\end{array}$ & \\
\hline Full Committee Vote & \\
\hline $\begin{array}{l}\text { Publication of Written Report on } \\
\text { Bill }\end{array}$ & \\
\hline Floor Action Scheduled on Bill & \\
\hline Bill Debated on Floor & \\
\hline Bill Voted on in Chamber & \\
\hline $\begin{array}{l}\text { Bill Referred to Other Chamber } \\
\text { (Generally Follows Same Route } \\
\text { Through Committee and Floor } \\
\text { Action) }\end{array}$ & \\
\hline $\begin{array}{l}\text { Bill Sent to Conference (Both } \\
\text { House and Senate Must Approve } \\
\text { Conference Report) }\end{array}$ & $\begin{array}{l}\text { Policy Rider Slipped Into } \\
\text { Appropriations Bill / Continuing } \\
\text { Resolution }\end{array}$ \\
\hline Bill Sent to President & $\begin{array}{l}\text { Appropriations Bill / Continuing } \\
\text { Resolution Sent to President } \\
\text { (Includes Policy Riders) }\end{array}$ \\
\hline
\end{tabular}

\section{Policy Riders Negate Public Notice and Comment}

Policy riders that are attached to basic legislation, and thus force the President to sign the bill into law, negate any public comment received throughout the rulemaking process. Under the Administrative Procedure 
Act ("APA"), when conducting informal rulemaking, administrative agencies are required to provide the public with adequate notice of a proposed rule followed by a meaningful opportunity to comment on the rule's content. ${ }^{172}$ Additionally, for matters of "great" importance, the APA requires the agency to allow for "more elaborate public procedures." 173 It would be nonsensical then for Congress to mandate the public's participation in the rulemaking process, but then later negate that important participation.

The DOL "fiduciary" rulemaking, ${ }^{174}$ discussed earlier in this Article, provides a good example of the importance of public participation. The DOL provided an extraordinarily lengthy and transparent notice and comment process, which included more than 160 days of open public comment, over 3,000 comment letters (including over 300,000 individual comments), and four days of public hearings with seventy-five witnesses. Throughout the comment process, Secretary of Labor Tom Perez and DOL staff held hundreds of meetings with Members of Congress, financial services firms and organizations, and consumer groups.

Members of Congress actively participated in the rulemaking process. Over one hundred Members of Congress provided comment on the DOL rulemaking. ${ }^{175}$ As noted above, Congressional participation in the rulemaking process is encouraged - it is entirely proper for Members of Congress to represent the interests of their constituents before administrative agencies engaged in informal, general policy rulemaking. ${ }^{176}$ This Article agrees that it was not unconstitutional for Congress to participate in the rulemaking.

However, while participation in the comment process was constitutional, the various attempts to stop the rulemaking process by Members of Congress was unconstitutional. In December 2015, lawmakers attempted to attach a rider to an omnibus spending bill that would "require the Department of Labor to publish its fiduciary rule for another comment period before finalizing the rule." 177 Additionally, in a

1725 U.S.C. $§ 553($ b)-(c) (Westlaw through Pub. L. No. 115-90).

173 Administrative Procedure ACt: Legislative History, S. Doc. No. 248, at 259 (1946).

174 Department of Labor, Definition of the Term "Fiduciary:" Conflict of Interest RuleRetirement Investment Advice, 81 Fed. Reg. 20,946 (Apr. 8, 2016) (29 C.F.R. Pts. 2509, 2510, 2550); Department of Labor, Best Interest Contract Exemption, 81 Fed. Reg. 21,002 (Apr. 8, 2016) (29 C.F.R. Pt. 2550).

175 Employee Benefits Security Administration, Comments on Conflict of Interest Proposed Rule, https://www.dol.gov/agencies/ebsa/laws-and-regulations/rules-andregulations/public-comments/1210-AB32-2 (last visited Dec. 27, 2017).

176 Sierra Club v. Costle, 657 F.2d 298, 409-10 (D.C. Cir. 1981).

177 Melanie Waddell, Spending Bill Rider Would Delay DOL Fiduciary Rule by Adding Comment Period, THINKADVISOR (Dec. 7, 2015), http://www.thinkadvisor.com/2015/12/07/ 
November 2016 letter, Senator Ron Johnson advised the DOL that implementation of the fiduciary rule should be halted, because the regulation "will very likely be rescinded." 178 The proposed policy rider and action requested in the letter would have violated the separation of powers by having the legislature interfere with the execution of the law, i.e., conducting a rulemaking to implement a statute, in this case ERISA. As noted above, "[i]nterpreting a law enacted by Congress to implement the legislative mandate is the very essence of "execution' of the law."

Congress, by using a policy rider to repeal or delay the rule, would be negating the voices of hundreds of thousands of individuals who participated in the rulemaking process. Interestingly, they will also be negating the voices of those Members of Congress who participated in the rulemaking process. This Article submits that the Constitution should not allow one Member of Congress to negate the voices of hundreds of thousands of American citizens by simply attaching a policy rider to a piece of legislation. ${ }^{180}$

\section{CASE STUdIES}

Stand-alone legislation directing agency action may also violate the Constitution. While this Article focuses on policy riders attached to appropriation bills, and these bills are currently stand-alone pieces of legislation, they could be added to a future appropriations bill. ${ }^{181}$

\section{A. Retail Investor Protection Act (H.R. 1090)}

In February 2015, Representative Ann Wagner, who represents Missouri's $2^{\text {nd }}$ District, ${ }^{182}$ introduced the Retail Investor Protection Act

spending-bill-rider-would-delay-dol-fiduciary-rule.

178 Letter from Ron Johnson, Sen. from Wisconsin, to Tom Perez, Dep't of Labor Sec'y (Nov. 22, 2016), http://www.hsgac.senate.gov/download/chairman-johnson-letter-to-dol-onfiduciary-rule.

179 Bowsher v. Synar, 478 U.S. 714, 733 (1986).

180 " $[\mathrm{I}] \mathrm{t}$ is proper you should understand what I deem the essential principles of our Government, and consequently those which ought to shape its Administration ... [such as] the diffusion of information and arraignment of all abuses at the bar of the public reason ...." President Thomas Jefferson, First Inaugural Address (Mar. 4, 1801) (transcript available at http://avalon.law.yale.edu/19th_century/jefinau1.asp).

181 Sen. Mike Lee, Restoring Congressional Accountability Through Appropriations Process, The Daily Signal (May 2, 2016), http://dailysignal.com/2016/05/02/restoringcongressional-accountability-through-appropriations-process/ ("As Congress proceeds through the appropriations process this Spring, each spending bill presents an opportunity to advance structural reforms that would restore congressional accountability over federal regulations.").

182 Press Release, Rep. Ann Wagner, Rep. Wagner Statement on the Introduction of the Retail Investor Protection Act (Feb. 25, 2015), https://wagner.house.gov/media-center/pressreleases/rep-wagner-statement-on-the-introduction-of-the-retail-investor (last visited Dec. 
("RIPA"). ${ }^{183}$ RIPA would prohibit the DOL from implementing its fiduciary rule until sixty days after the Securities and Exchange Commission ("SEC") issues a final rule governing standards of conduct for brokers and dealers under specified law. ${ }^{184}$ RIPA amends sections of the Securities Exchange Act of 1934; ${ }^{185}$ however, this Article will focus on the section concerning the DOL fiduciary rule.

RIPA, if enacted, would violate the Constitution. First, it is unlawful under current Supreme Court precedent. In Sierra Club, the Supreme Court held that Congressional interference could be unlawful if the "content of the pressure on the [decisionmaker] is designed to force him to decide upon factors not made relevant by Congress in the applicable statute" and also that the determination made "must be affected by those extraneous considerations." 186 Following the Supreme Court's reasoning, in ATX, Inc. v. United States Department of Transportation, the DC Circuit held that "an administrative decision must be based 'strictly on the merits and completely without regard to any considerations not made relevant by Congress in the applicable statutes." "187 RIPA would force the DOL to base its implementation of the fiduciary rule on the actions of another government agency ("SEC"), rather than the applicable factors under ERISA. These factors include, but are not limited to, increasing "the likelihood that participants and beneficiaries under single-employer defined benefit pension plans will receive their full benefits." 188

Second, RIPA violates the separation of powers under the Constitution. Forcing the DOL to stop implementation of its fiduciary rule, ${ }^{189}$ which has the force of law, ${ }^{190}$ effectively removes DOL's ability to faithfully execute the laws under the Constitution. It is important to note that RIPA does not amend the underlying ERISA statute, but rather

\footnotetext{
27, 2017).

183 Retail Investor Protection Act, H.R. 1090, 114th Cong. (2015).

184 H.R. 1090, 114th Cong. § 2.

18515 U.S.C. $\$ 78$ (Westlaw through Pub. L. No. 115-90).

186 Sierra Club, 657 F.2d at 409-10.

187 ATX, Inc. v. United States Dep't of Transp., 41 F.3d 1522, 1530 (D.C. Cir. 1994) (quoting D. C. Fed'n of Civic Ass'ns v. Volpe, 459 F.2d 1231, 1246 (D.C. Cir. 1971)).

18829 U.S.C. $\S 1001$ b(c)(3) (Westlaw through Pub. L. No. 115-90).

189 See Springer v. Gov’t of Philippine Islands, 277 U.S. 189, 202 (1928); see also J.W. Hampton, Jr. \& Co. v. United States, 276 U.S. 394, 406 (1928).

190 New York v. FCC, 486 U.S. 57, 63 (1988) ("The Supremacy Clause of the Constitution gives force to federal action of this kind by stating that 'the Laws of the United States which shall be made in Pursuance' of the Constitution 'shall be the supreme Law of the Land.' U.S. Const., Art. VI, cl. 2. The phrase 'Laws of the United States' encompasses both federal statutes themselves and federal regulations that are properly adopted in accordance with statutory authorization.").
} 
it directs DOL to not implement a properly created federal law.

\section{B. Protecting American Families' Retirement Advice Act (H.R. 355)}

In January 2017, Representative Joe Wilson, who represents South Carolina's $2^{\text {nd }}$ District, ${ }^{191}$ introduced the Protecting American Families' Retirement Advice Act (H.R. 355). ${ }^{192}$ The Act would require the DOL to delay the effective date of its fiduciary rule for two years from the date of the legislation.

The Act violates the separation of powers under the Constitution. Forcing the DOL to stop implementation of its fiduciary rule, ${ }^{193}$ which has the force of law, ${ }^{194}$ effectively removes DOL's ability to faithfully execute the laws under the Constitution. Significantly, similar to RIPA, the Act does not amend the underlying ERISA statute, but it does direct DOL to not implement a properly created federal law.

\section{Require Evaluation before Implementing Executive Wishlists Act (H.R. 3438)}

In September 2016, Representative Tom Marino, who represents Pennsylvania's $10^{\text {th }}$ District, ${ }^{195}$ introduced the Require Evaluation before Implementing Executive Wishlists Act of 2016 ("REVIEW Act") (H.R. 3438). ${ }^{196}$ The REVIEW Act would require agencies to postpone the effective date of high-impact rules ( $\$ 1$ billion impact on the economy) until the final disposition of all actions seeking judicial review of the rule. ${ }^{197}$

The REVIEW Act would illegally interfere with the President's constitutional duty to "take care that the laws be faithfully executed." 198 It effectively stops an administrative agency from implementing a regulation until any litigation brought against the agency with respect to

191 Press Release, Rep. Joe Wilson, Wilson Introduces the Protecting American Families' Retirement Advice Act (Jan. 6, 2017), https://joewilson.house/gov/media-center/pressreleases/wilson-introduces-the-protecting-american-families-retirement-advice-act.

192 Protecting American Families' Retirement Advice Act, H.R. 355, 115th Cong. (2017).

193 See Springer, 277 U.S. at 202; see also Hampton, 276 U.S. at 406.

194 New York, 486 U.S. at 63.

195 Press Release, Rep. Tom Marino, Reps. Marino, Goodlatte Applaud Committee Passage of Bill to Stop "High Impact” Regulations (Sept. 8, 2016), https://marino.house.gov/ media-center/press-releases/reps-marino-goodlatte-applaud-committee-passage-bill-stophigh-impact.

196 Require Evaluation before Implementing Executive Wishlists Act, H.R. 3438, 114th Cong. (2016).

197 H.R. $3438 \S 3$.

198 U.S. CONST. art. II, § 3. 
the rulemaking has concluded. In Bowsher, the Supreme Court ruled that Congress may not, "in practical terms, reserve... control over the execution of the laws." 199 By not allowing agencies to implement rules in a timely fashion, this is exactly what the REVIEW Act allows Congress to do.

\section{Regulations from the Executive in Need of Scrutiny Act (H.R. 427)}

In July 2015, now Senator Todd Young, who at the time was a Congressman representing Indiana's $9^{\text {th }}$ District, introduced the Regulations from the Executive in Need of Scrutiny Act ("REINS Act"). ${ }^{200}$ The REINS Act would require "a joint resolution of approval of major rules to be enacted before such rules may take effect" and that "if a joint resolution of approval is not enacted by the end of 70 session days or legislative days, as applicable, after the agency proposing the rule submits its report on such rule to Congress, the major rule shall be deemed not to be approved and shall not take effect."201

The REINS Act would impermissibly interfere with the President's constitutional duty to "take care that the laws be faithfully executed." 202 It effectively allows Congress, the branch that creates laws, to also control the execution of those laws. As noted in Chadha, "Congress must abide by its delegation of authority until that delegation is altered or revoked."203 In Bowsher, the Supreme Court ruled that Congress may not, "in practical terms, reserve ... control over the execution of the laws." 204 Unfortunately, this is exactly what the REINS Act would accomplish.

\section{SOLUTIONS}

\section{A. Enforce Congressional Rules}

The simplest solution to the use of appropriation riders is for Congress to enforce their own rules and not allow Members of Congress to waive the rules concerning the attachment of substantive legislation to appropriation bills. As noted above, legislating through appropriation riders violates both Senate and House rules-generally legislative

199 Bowsher v. Synar, 478 U.S. 714, 715 (1986).

200 Regulations from the Executive in Need of Scrutiny Act, H.R. 427, 114th Cong. (2015).

201 H.R. 427 § 3.

202 U.S. CONST. art. II, § 3.

203 INS v. Chadha, 462 U.S. 919, 955 (1983).

204 Bowsher, 478 U.S. at 715. 
provisions may not be included in appropriation bills. ${ }^{205}$

This Article proposes two methods for handling policy riders. The first is to draft legislation that would codify the current Congressional guidance with respect to legislating in appropriation bills and remove Congress' authority to waive those rules. The second would be to draft legislation that would mandate greater transparency in the appropriations process with respect to the addition of policy riders. While this Article submits that many policy riders are unconstitutional, politically it will be very difficult to ban this practice entirely.

\section{Option 1: Prohibiting Policy Riders}

\section{AN ACT}

To amend chapter 43 of title 2, United States Code, to provide that substantive policy riders may not be attached to appropriations bills and/or continuing resolutions.

Be it enacted by the Senate and House of Representatives of the United States of America in Congress assembled,

SEC. 1. SHORT TITLE.

This Act may be cited as the "Removing Policy Riders from the Appropriations Process Act of 2017".

\section{SEC. 2. PURPOSE.}

The purpose of this Act is to increase accountability in the appropriations process. Section 3 of article 2 of the United States Constitution mandates that the President shall ensure faithful execution of the laws passed by the legislature. Over time, Congress has consistently intruded upon this executive branch authority by attaching policy riders to appropriations bills that interfere with the executive's power to interpret and execute laws passed by Congress. In effect, Congress has acquired control over the execution of the laws. By removing Congress's ability to attach policy riders to appropriations bills that would interfere with executive enforcement of the law, the Act will result in an improved regulatory process, and a legislative branch that is truly accountable to the American people for the laws imposed upon them.

\section{SEC. 3. REMOVING POLICY RIDERS FROM THE} APPROPRIATIONS PROCESS.

Chapter 43 of title 2, United States Code, is amended to read as follows:

CHAPTER 43-CONGRESSIONAL COMMITTEES

Sec. 4304. Prohibition on Substantive Limitation Policy 
Riders in Appropriations Bills.

Legislative provisions containing language that place substantive limitations on agencies' implementation of statutory law and interferes with the execution of statutory law in the appropriations process are prohibited from being reported in general appropriations bills and amendments to appropriations bills.

4305. Prohibition on Substantive Limitation Policy Riders in Continuing Resolutions.

Legislative provisions containing language that places substantive limitations on agencies' implementation of statutory law and interferes with the execution of statutory law are prohibited from being reported in a continuing resolution.

\title{
Option 2: Increasing Transparency in the Appropriations Process
}

\begin{abstract}
AN ACT
To amend chapter 43 of title 2, United States Code, to increase transparency with respect to substantive policy riders attached to appropriations bills and/or continuing resolutions.
\end{abstract}

Be it enacted by the Senate and House of Representatives of the United States of America in Congress assembled,

SECTION 1. SHORT TITLE.

This Act may be cited as the "Increasing Transparency in the Appropriations Process Act of 2017".

\section{SECTION 2. PURPOSE.}

The purpose of this Act is to increase transparency in the appropriations process. Section 3 of article 2 of the United States Constitution mandates that the President shall ensure faithful execution of the laws passed by the legislature. Over time, Congress has consistently intruded upon this executive branch authority by attaching policy riders to appropriations bills that interfere with the executive's power to interpret and execute laws passed by Congress. In effect, Congress has acquired control over the execution of the laws. By requiring Congress to be more transparent with respect to policy riders, the Act will result in a legislative branch that is truly accountable to the American people for the laws imposed upon them.

\section{SEC. 3. INCREASING TRANSPARENCY IN THE APPROPRIATION PROCESS.}

Chapter 43 of title 2, United States Code, is amended to read as follows:

\section{CHAPTER 43-CONGRESSIONAL COMMITTEES}


Sec. 4304. Increasing Transparency for Policy Riders in Appropriations Bills.

(a) Appropriations Committee staff shall create a central list of all policy riders included in an appropriations bill. The list shall:

(1) include a section describing the purpose and intent of each rider, along with the expected impact on taxpayers and the economy;

(2) be made available to the public in a machine readable format in advance of any vote on the appropriations bill.

(b) Appropriations Committee staff shall highlight the policy riders in the text of the appropriations bill so interested parties can easily find the language in the bill.

4305. Increasing Transparency for Policy Riders in Continuing Resolutions.

(a) Appropriations Committee staff shall create a central list of all policy riders included in a continuing resolution. The list shall:

(1) include a section describing the purpose and intent of each rider, along with the expected impact on taxpayers and the economy;

(2) be made available to the public in a machine readable format in advance of any vote on the continuing resolution.

(b) Appropriations Committee staff shall highlight the policy riders in the text of the continuing resolution so interested parties can easily find the language in the bill.

\section{B. Limited Line Item Veto}

Congress could create legislation that would allow for a line item veto limited to policy riders in appropriation bills or continuing resolutions. This legislation would allow: (1) policy riders to be attached to appropriation bills and continuing resolutions; (2) President to veto individual policy riders without having to veto the entire spending bill; and (3) Congress to override the individual veto. This is a policy proposal advanced by the non-profit group No Labels. ${ }^{206}$

206 Understanding the Line-Item Veto with a Twist, No LABELS, https://www.nolabels.org /understanding-the-line-item-veto-with-a-twist/ (last visited Dec. 27, 2017). 
In Clinton v. City of New York, the "Supreme Court found that the line-item veto violated the Presentment Clause of the Constitution, which says that the president does not have the power to unilaterally amend or repeal legislation passed by Congress." ${ }^{207}$ However, No Labels contends, and this Article agrees, by sending the rescinded part of the bill back to Congress for an expedited up or down vote, a limited line item veto complies with the Presentment Clause of the Constitution and the Supreme Court's ruling in Clinton. ${ }^{208}$

This procedure would allow the President to separate controversial policy riders from must-pass spending legislation, and would also provide Congress with the ability to move forward by overriding the President's veto with respect to individual policy riders.

In 2006, Representative Paul Ryan introduced similar legislation known as the Legislative Line Item Veto Act of 2006. ${ }^{209}$ This bill would have authorized "the President to propose the cancellation (line item veto) of any dollar amount of discretionary budget authority, item of direct spending, or targeted tax benefit within 45 days after its enactment."210 The bill passed the House, but was not considered in the Senate. While this bill is similar, this Article contends that the No Labels proposal is more appropriate.

\section{CONCLUSION}

Congress has slowly increased its control over the activities of the executive branch, through directly influencing administrative proceedings and through the use of substantive policy riders in the appropriations process. In sum and substance, Congress has unconstitutionally acquired control over the execution of laws. This Article submits that these actions are unconstitutional and must be challenged. Over two hundred years ago, George Mason, then a delegate to the United States Constitutional Convention of 1787, issued a warning regarding "the practice of tacking foreign matter[s] to money bills." 211 Today, this concern is even greater, with Congress freely adding policy riders to appropriation bills, many of which receive little to no debate or public scrutiny. This practice must be prohibited, or in the alternative, it must be more transparent.

\footnotetext{
207 Id. (citing Clinton v. City of New York, 524 U.S. 417, 421 (1998)).

$208 I d$.

209 Legislative Line Item Veto Act of 2006, H.R. 4890, 109th Cong. (2006).

210 H.R. 4890 § 1.

211 Colonel George Mason, Statement at U.S. Constitutional Convention (Aug. 13, 1787) (transcript available at http://avalon.law.yale.edu/18th_century/debates_813.asp).
} 